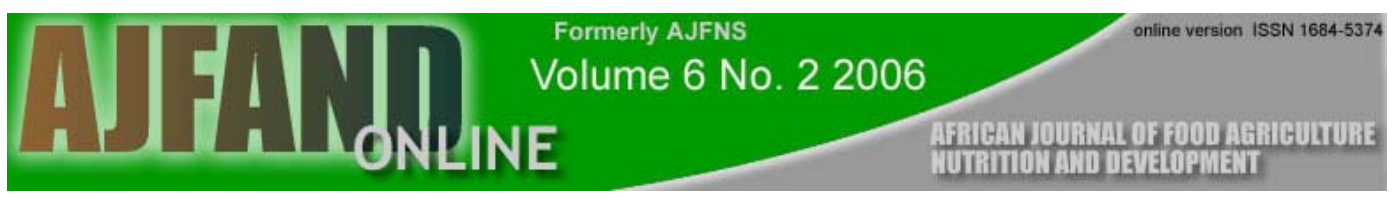

\title{
EXTRACTION AND QUALITATIVE ASSESSMENT OF AFRICAN SWEET ORANGE SEED OIL
}

Nwobi BE, Ofoegbu O* and O B Adesina

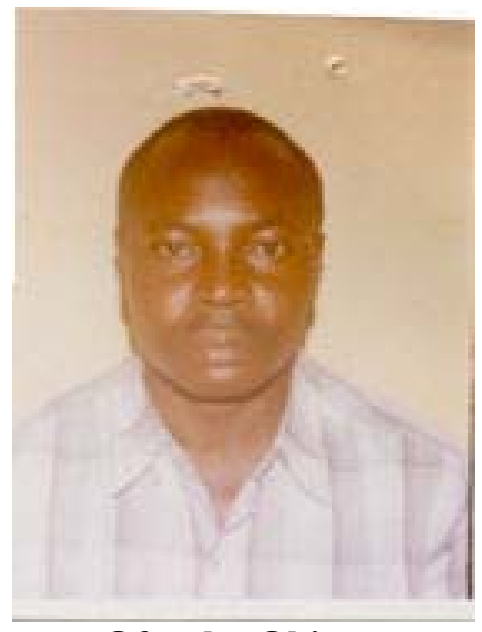

Ofoegbu Obinna

*Corresponding author

National Research Institute for Chemical Technology

P.M.B. 1052 Zaria-Kaduna

e-mail obinnafor@yahoo.co.uk 


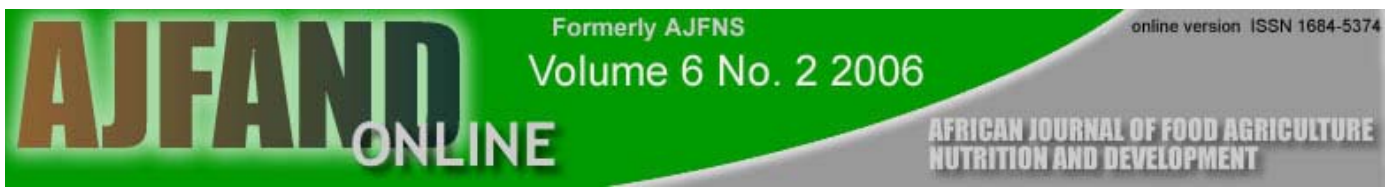

\section{ABSTRACT}

The African sweet orange fruit Citrus Sinensis seeds were obtained from discards of fruits and prepared for use by decoating, sun drying and grinding. By solvent extraction using petroleum ether, a golden yellow coloured oil was obtained and characterized by determining the $\mathrm{pH}$, refractive index, density, solvent miscibility, congealing temperature, flame nature, specific gravity, retention factor on chromatographic plate, heat of combustion, smoke point, flash point, fire point, and the percentage yield. In addition, the spectroscopic analysis was carried out using Genesis FTIR spectrophotometer. The free fatty acid, unsaponifiable matter, saponification, iodine, acid and peroxide values were determined according to the standard method of analysis. Oil yield of $36 \%$ was obtained. The results show a high degree of unsaturation, presence of reasonable amount of free fatty acids, marked level of oiliness, refractive index $\left(1.47\right.$ at $\left.25^{\circ} \mathrm{C}\right)$, high level of acid value $82 \%(0.82)$ - with the presence of palmitic, stearic, oleic acid, traces of linoleic acid-and interestingly, absence of linolenic, myristic and arachidic acids. The solvent miscibility of the oil was determined by physical observation of the uniform blending of oil sample in acid $(\mathrm{HCl})$, alkali $(\mathrm{NaOH})$, sodium hydrogen carbonate solution, carbonate solution, ether and water at room temperature, 40 ${ }^{\circ} \mathrm{C}, 60^{\circ} \mathrm{C}, 80^{\circ} \mathrm{C}$ and $100{ }^{\circ} \mathrm{C}$. The low value of the congealing temperature of the oil gave an indication that the oil can be handled in very many geographical regions irrespective of the difference in temperature values of such regions. The trace level content of linoleic acid of the oil confers on it a high degree of stability. The IR shows peaks at $1377.33,1237.05,1163.43$ and $1100.14 \mathrm{~cm}^{-1}$, which are indicative of the presence of carboxylic acids, and these are vital elemental composition of fatty acid compounds. The presence of the multiple peaks at $1100.14 \mathrm{~cm}^{-1}$ in the IR chart depicts an isopropyl group presence which is also indicative of a cis-alkene groups presence, suggestive of the stable bond structure of the oleic acid family. 


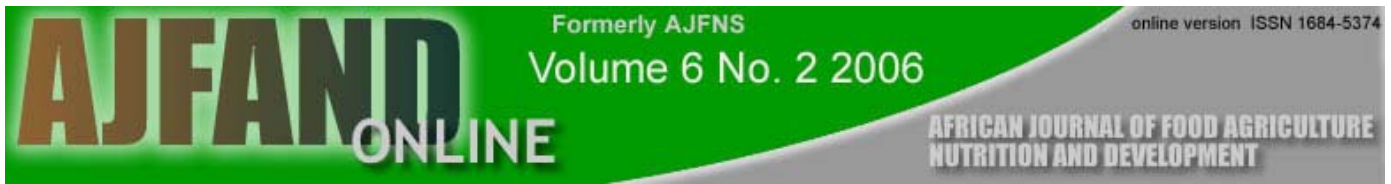

French

EXTRACTION ET ÉVALUATION QUALITATIVE DE L'HUILE DE GRAINE DE L'ORANGE AFRICAINE DOUCE

RÉSUMÉ

Les graines de l'orange africaine douce Citrus Sinensis ont été obtenues des rejets de fruits et préparées pour leur utilisation grâce au procédé de décorticage, de séchage au soleil et de broyage. Une huile de couleur jaune or a été obtenue par extraction de dissolvant en utilisant l'éther de pétrole. Les caractéristiques de cette huile ont été spécifiées en déterminant le $\mathrm{pH}$, l'indice de réfraction, la densité, la miscibilité de dissolvant, la température de congélation, la nature de la flamme, la gravité spécifique, le facteur de rétention sur une plaque chromatographique, la chaleur de combustion, le point de fumigation, le point d'éclair, le point de combustion, et le pourcentage du rendement. En plus, l'analyse spectroscopique a été menée en utilisant le Spectrophotomètre Genèse FTIR. Les valeurs d'acide gras libre, de matière non saponifiable, de saponification, d'iode, d'acide et de peroxyde ont été déterminées selon la méthode standard d'analyse. Un rendement de $36 \%$ de matières grasses a été obtenu. Les résultats montrent un niveau élevé de non saturation, la présence de quantités raisonnables d'acides gras libres, un aspect huileux prononcé, un indice de réfraction $\left(1,47\right.$ à $\left.25{ }^{\circ} \mathrm{C}\right)$, un niveau élevé de valeur acide $82 \%(0,82)$ - avec la présence d'acide palmitique, stéarique, oléique, des traces d'acide linoléique — et de façon intéressante, l'absence d'acides linoléiques, myristiques et arachidiques. La miscibilité du dissolvant de l'huile a été déterminée par l'observation physique du mélange uniforme de l'échantillon d'huile dans l'acide $(\mathrm{HCl})$, l'alcali $(\mathrm{NaOH})$, la solution de carbonate d'hydrogène de sodium, la solution de carbonate, l'éther et l'eau à la température ambiante, $40^{\circ} \mathrm{C}, 60^{\circ} \mathrm{C}, 80^{\circ} \mathrm{C}$ et $100^{\circ} \mathrm{C}$. Le bas niveau de la température de congélation de l'huile a révélé qu'elle peut être manipulée dans de nombreuses régions géographiques sans tenir compte des différences entre les valeurs des températures de ces régions. Le niveau de la trace de la composante d'acide linoléique de l'huile lui confère un degré élevé de stabilité. L'IR montre des pointes à $1377,33,1237,05,1163,43$ et $1100,14 \mathbf{c m}^{-1}$, qui sont indicatifs de la présence d'acides de carboxylique, et ceux-ci sont des substances essentielles des composés d'acides gras. La présence des points multiples à $1100.14 \mathrm{~cm}^{-1}$ dans le graphique d'IR dépeint une présence du groupe d'isopropyle qui révèle également de la présence du groupe cis-alkene, suggestive de la structure stable de lien de la famille d'acide oléique. 


\section{INTRODUCTION}

Mixtures of fatty acid esters of the trihydroxy alcohol or glycerol are commonly known as edible fats and oils [1], and they are obtained from fruits, nuts, seeds and roots of plants and vegetables [2]. Some organic polar compounds that form part of the food store of the seeds and nuts, has differing levels of food and medical values [3]. This chemical constituent can be obtained from the oily part of the seed when extracted [4].

The African sweet orange fruit is a specialized berry known as Citrus Sinensis, which belongs to the race var. sinensis, the fruit size varies with cultivar and crop load, but most oftenly measures between 2.5-4 inches in diameter. The shape of the fruit is spherical to oblong, with a peel thickness between that of grape fruit and tangerine, and is either smooth or roughly pebbly[5]. It is usually very closely adhered to the flesh of the fruit. Its colour tints from green to light orange, depending on the cultivar. The presence and amount of seed, depends also on cultivar, starting from seedy (15 to 25 seeds/fruit) as is observed in 'pearson brown' and 'queen' species respectively.

The extraction and characterization of oils from fruit seeds have been carried out extensively, but little have been reported on the physio-chemical properties of the oil from the seed of African sweet orange, despite an initial attempt by some authors who worked on the seeds of closely related lime seeds $[6,7,8,9]$.

The extraction and commercialization of this oil will reasonably enhance the profit status of most fruit juice making industries, and encourage the sustenance of the cultivation of the seedy species of sweet orange fruits.

The chemical composition of the oil extract consequently gives a qualitative identification of oils, and is a very important area in the selective application guide in the commercialization and utility of oil products. Such analysis as the iodine value, gives an index of the drying and polymerizing properties of oil, while flash points indicate a substantial removal of solvent from a solvent-extracted oil-like the one being discussed where a standard of not below $250{ }^{\circ} \mathrm{F}\left(121.1{ }^{\circ} \mathrm{C}\right)$ - is required, for example by the open cup method of analysis [10].

Apart from establishing the identity of oils, proximate analytical data expresses the particular type or grade of oil, despite the varying properties and processing characteristics of oils, due to geographical origin and the method of extraction from the oil-bearing material. It is then very important to obtain the specific data for samples of oil from a particular area, because there exist a range of free fatty acid content of these oils due to geographical origin, eg, Maloyan, Congo, Lagos, Niger palm oils or Ceylon, cochin coconut oils, etc [11].

The characterisation based on different fatty acid groups, gives an insight into the distribution of acids in the unsaturated fraction among oleic, linoleic and linolenic acids as is the case with the linolenic acid group, though it is not a conclusive pointer. In a 
general form of summation, oils can be classed under fatty acid groups predominant in them and such groups can be itemized as; (a) milk fat, (b) lauric acid, (c) vegetable butter, (d) animal fat, (e) oleic-linoleic acid, (f) euric acid, (g) linolenic acid, (h) conjugated acid, (i) marine oil and (j) hydroxy acid. Whichever group the African sweet orange seed oil falls into, will be indicated by the result of the analysis of the free fatty acid present in the oil./

Finally, the aim of this work is to find use for the seeds of the African sweet orange which were being wasted, by extracting the oil and assessing the quality of the oil so extracted, in order to know in what industry it can be best utilized.

\section{METHODS AND MATERIALS}

The fruit seeds were obtained from local fruit vendors. They were prepared for use by decoating, sun drying and grinding. A Soxhlet extractor was used for solvent extraction of the oil. The solvent (Pet ether) was removed from the extract by distillation and the residual oil component collected and used for the analytical work. A 5 liter capacity soxhlet extractor was used in the extraction of the oil from the ground seeds. $200 \mathrm{~g}$ of the ground seeds were packed in a whatman filter paper and inserted into the soxhlet extractor and a $40{ }^{\circ} 60{ }^{\circ} \mathrm{C}$ petroleum ether (BDH analar grade) was used as the extracting solvent. The period of continuous extraction was 16 hours [12]. At the end of this period, the solvent was recovered by simple distillation and the residual oil was oven-dried at $65{ }^{\circ} \mathrm{C} \pm 2{ }^{\circ} \mathrm{C}$ for one hour. The oil was then transferred to a desiccator and allowed to cool, before being weighed. The drying, cooling and weighing was repeated until a constant dry weight was obtained (three cycles of treatment), to within $0.01 \mathrm{~g}$. The extracted oil sample was in a well sealed dark brown coloured glass bottle and kept for analytical tests.

$\mathbf{p H}$ of the oil was determined according to the official method of analysis of the Society of Leather Trades' Chemists SLTC [10].

Density was determined using a density bottle at $25{ }^{\circ} \mathrm{C}$ and this is the ratio of the mass of the oil to its volume.

Solvent miscibility of the oil was determined by physical observation of the uniform blending of oil samples in acid (HCL), alkali $(\mathrm{NaOH})$, sodium hydrogen carbonate solution, ether and water at room temperature, $40{ }^{\circ} \mathrm{C}, 60{ }^{\circ} \mathrm{C}, 80{ }^{\circ} \mathrm{C}$ and $100{ }^{\circ} \mathrm{C}$.

The nature of the flame of burning oil sample was determined by heating the oil in a stainless saucer and at the start of smoke, placing a clean white ceramic plate $25 \mathrm{~cm}$ above the oil sample, and the ceramic plate is removed after a period of about 20 mins and observed for the presence of sooth.

The congealing temperature was determined crudely by putting $20 \mathrm{mls}$ of the dried oil sample in a $100 \mathrm{ml}$ beaker and inserting a simple laboratory thermometer into the oil

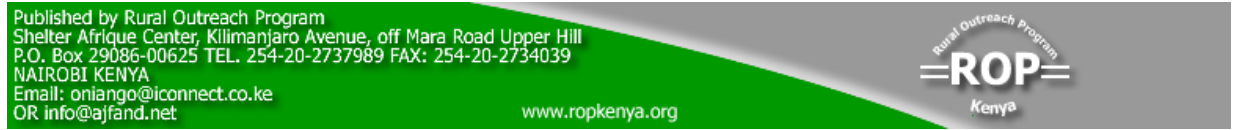


and putting it in a freezer. The oil sample was closely monitored as the temperature reduced. The temperature at which the initially fluid oil sample starts getting jelly was noted, and the temperature at which gellation took place within the oil was also noted and an average of the two gave approximate congealing temperature.

Spectroscopic analysis of the oil was carried out using Genesis FTIR spectrophotometer with the aid of sodium chloride cells. A thin layer chromatography of the oil sample was done using a silica gel sprayed on a glass slide and a spot of the oil sample eluted with n-hexane. The refractive index, specific gravity, heat of combustion, smoke point, flash point and fire point were determined using standard methods [13].

The oil sample was then taken for determination of acid value, free fatty acid, saponification value, iodine value, peroxide value and unsaponifiable matter according to the standard method of analysis [11].

\section{RESULTS}

Table I shows the physio-chemical properties of African Sweet Orange Seed Oil. The yield of the seed oil was found to be about $36 \%$. The $\mathrm{pH}$ value of 3.69 suggests that the oil is acidic, which is indicative of the presence of fatty acids in the extracted oil.

The oil was found to be miscible with ether, which shows that the oil contains unsaturated fatty acids that confers on its industrial utility.

The oil was found to have a congealing temperature of - $12-20{ }^{\circ} \mathrm{C}$. The refractive index of the oil was 1.47 at $25^{\circ} \mathrm{C}$, while the $\mathrm{Rf}$ value was determined to be $1.5 \mathrm{~cm}$.

Table II shows the result of the proximate analysis of the oil. The acid value of the oil was found to be $82 \%$, while the oil had the saponification value of 192 . The unsaponifiable matter content of the oil was found to be $0-7$.

The iodine value and peroxide value of the African sweet orange seed oil were determined to be 108 and 92.84 respectively.

\section{DISCUSION}

The value of the product yield makes the industrial practice of the oil recovery a profitable venture, and will reduce the level of waste that is obtained from the juicemaking industry. Furthermore, the positive economic implication stated that other deductions can be made by a careful look at the parameters available.

The low $\mathrm{pH}$ level is indicative of the presence of a reasonable amount of fatty acids in the oil, which is a good indicator of the advantageous utilization of the oil as a result of the presence of free fatty acids. 
The preferential solubility in the ether shows that the oil has a high level of unsaturated fatty acids - bearing in mind that oils rich in unsaturated fractions are readily soluble in ether - while those rich in saturated fractions are insoluble in ether. The presence of a high amount of unsaturated fatty acids in the oil identifies the oil as one that can undergo polymerization and this imparts on the oil a level of industrial utility [10].

The smoke, flash and fire points of the oil has a linear relationship with the content of free fatty acids present. With the data, a free fatty acid content of $0.01 \%$, a corresponding smoke point of $232{ }^{\circ} \mathrm{C}$ is obtained, while for a free fatty acid content of $100 \%$, a smoke point of $93{ }^{\circ} \mathrm{C}$ and these results were obtained for corn oil, cotton seed oil and peanut oil - that have a closely observed properties with the orange seed oil [10]. Advantageously, the higher the amount of fatty acid present in an oil sample, the higher the nutritional value, consequently the orange oil with a smoke point of $149{ }^{\circ} \mathrm{C}$, deductively has a good degree of free fatty acid.

The low values of congealing temperature of the oil gives an indication that oil can be handled in very many geographical regions, not minding the temperature differences. For instance, at a temperature as low as $-6{ }^{\circ} \mathrm{C}$ the oil will still be fluid and able to flow.

The refractive index of 1.47 and the retention factor/Rf value of the chromatogram shows the degree of purity of the oil. Though the result may change with different methods of extraction, the level of purity desired can easily be obtained by little process modifications, like filter pressing or centrifugation.

The IR chart shows peaks at 1377.33, 1237.05, 1163.43 and $1100.14 \mathrm{~cm}^{-1}$ which are indicative of the presence of carboxylic acids ( Figure 1) and these are vital elemental composition of fatty acid compounds. The $110.14 \mathrm{~cm}^{-1}$ multiple peak depicts an isopropyl group's presence - which is also indicative of a cis-alkene group's presence, suggestive of the soluble bond structure of the oleic acid family. The peak at $722.46 \mathrm{~cm}^{-}$ ${ }^{1}$ is indicative of the presence of an alkene group of the linoleic acid family.

The presence of more than one fatty acid in the oil gives it the status of a mixed triglyceride or compound glyceride the presence of oleic (Octadec - 9 - enoic) and linoleic (Octadeca 9, 12 - dienoic) acids in the oil, classifies the African Orange Seed Oil as belonging to the oleic-linoleic group of fatty acids.

Though the presence of methylene groups in an oil encourages autoxidation, the presence of only two methylene groups in the structure of the predominant unsaturated fatty acid present in the orange seed oil (oleic acid) - which is without conjugation confers a reasonable degree of stability to the oil. With careful processing and handling, the oil can be stored for a good period of time without autoxidation taking place despite the high peroxide value [14].

The value of the saponification number, projects the oil in good light in such areas as soap making and in the detection of adulteration of the oil. The saponification value of

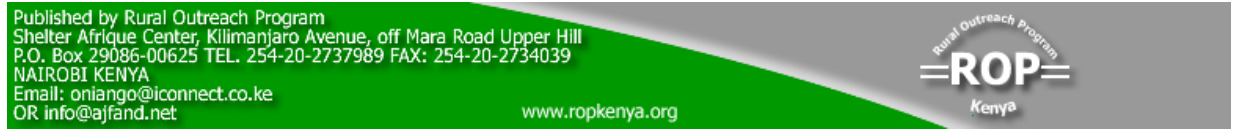


192 indicates that the oil has a saponification equivalent of 292.21, which means that $292.21 \mathrm{~g}$ of the oil will be saponified by $56.104 \mathrm{~g}$ of potassium hydroxide, ie, going by the relationship; (saponification number) (saponification equivalent ) = 56, 104 [15]. This gives an indication of the amount or number of mole of potassium hydroxide that will be required in the complete saponification of the oil during the manufacture of soap.

The value of the iodine number (108) places the oil in a position in-between the nondrying and semi-drying oils. By implication, the oil can be easily converted into a semidrying oil for use in the production of paints and vanish, while it may also be used as a non drying oil in the lubricant industry. The value also shows the moderate level of unsaturation of the oil.

The stability of the oil can be reasoned to be because of the absence or traces of linoleic acid in the oil. This is because it is known that the readily formed peroxides of linoleic acid and other polyethenoid acids catalyses the autoxidation of oleic acid - is the primary cause of oxidative rancidity [16]. Therefore, the absence of these polyethnoid acids is consequent to the stability of the oil.

The golden-yellowish colour may be an indication of the presence of carotene which bears the important vitamin A, giving the oil a medicinal value. The absence of linolenic acid makes the oil free from serious tendency toward flavour reversion, and as such, makes it good for edible purposes.

\section{CONCLUSION}

In view of the findings, we stand to recommend the industrial extraction and commercialization of the seed oil from African orange fruit in industrial manufacturing processes in such areas as, resin, pharmaceutical and manufacture of food/beverage.

The chemical composition of the African sweet orange seed oil differs remarkably from those of different geographical locations [5]. That is Jamaica, Ceylon and hyderabad, which have compositional linoleic acid contents of 54.2, 34.2 and $37.1 \%$, respectively, as against the traces found in African sweet orange species. This may serve as a distinguishing factor and guide against adulteration.

Finally, we strongly recommend the encouragement of the industrial production of this seed oil. 


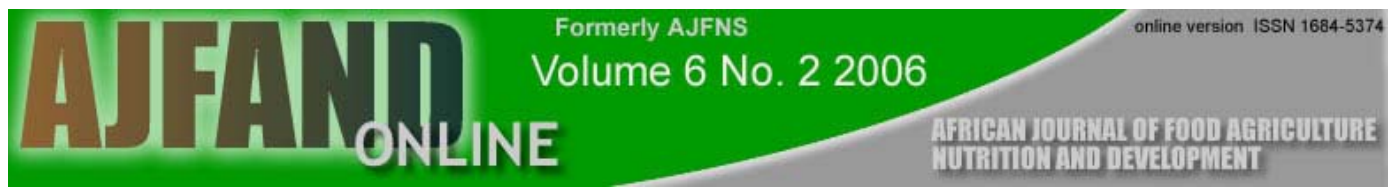

\section{ACKNOWLEDGEMENT}

We are immensely grateful to the staff of the Department of Food and Agricultural Research, IAR, ABU. Zaria for their assistance in carrying out the laboratory analysis of the oil sample.

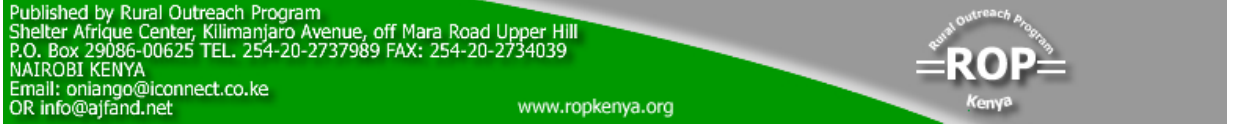


Table I. Physio-chemical properties of African Sweet orange Seed Oil

\begin{tabular}{|l|l|}
\hline Test & Result \\
\hline PH & 3.69 \\
\hline Refractive index & 1.47 at $25{ }^{\circ} \mathrm{C}$ \\
\hline Specific gravity & 0.920 at $15^{\circ} \mathrm{C}$ \\
\hline Retention factor (Rf value) & $1.5 \mathrm{~cm}$ \\
\hline Congealing temperature & -12 to $-20{ }^{\circ} \mathrm{C}$ \\
\hline Smoke point & $149{ }^{\circ} \mathrm{C}$ \\
\hline Flash point & $151{ }^{\circ} \mathrm{C}$ \\
\hline Fire point & $173{ }^{\circ} \mathrm{C}$ \\
\hline Heat of combustion & $9.515 \mathrm{kCal} / \mathrm{g}$ \\
\hline Flame nature & Non sooty \\
\hline Solvent miscibility & Soluble in ether \\
\hline Product \% yield & $36 \%$ \\
\hline
\end{tabular}

Table II. Proximate analysis result of oil sample

\begin{tabular}{|l|l|}
\hline ANALYSIS & RESULT \\
\hline Acid value & $82 \%$ \\
\hline Saponification value & 192 \\
\hline Iodine value & 108 \\
\hline Peroxide value & 92.84 \\
\hline Unsaponifiable matter & 0.7 \\
\hline Free fatty acids & \\
Saturated & \\
Palmitic acid & $5.8 \%$ \\
\hline Stearic acid & $4 \%$ \\
\hline Myristic cid & Nil \\
\hline Arachidic acid & Nil \\
\hline Unsaturated & $56 \%$ \\
\hline Oleic acid & Traces \\
\hline Linoleic acid & Nil \\
\hline Linolenic acid &
\end{tabular}




\section{REFERENCES}

1. Hamilton ML and MY Raie J.Am. Oil Chemist So. 1972 49, 307-10.

2 Subramanian VVR and KT Achaya J.Sci. Food Agric 1960.,8 662.

3 Eckey EW Vegetable Fats and Oils, 1954 Reinhold, New York.

4 Altschul AM Processed plant protein food stuffs, Academic press, New York.

$5 \quad$ Hilditch TP J oil Colour Chemists’'Assoc., 1950 32 5-21.

6 Hutchins RP Short Course On Engineering Aspects of Processing Edible Oils, J.Am. Oil Chemists' Soc., 1953 30, 473-582.

7 Marley KS Fatty Acids, Interscience, 1960-1961 (New York).

$8 \quad$ Mattson FH and ES Lutton J. Biol. Chem, 1958 233, 868-71.

9 Salunke DK et al., World oilseeds chemistry, technology and utilization, Culinary and Hospitality Industry Pub. Services. 1998-2004.

10 SLTC The Society of Leather Traders Chemists Official methods of Analysis. 1963.

11 AOCS American Oi.l Chemists Society.official and Tentative methods 1947.

12 AOCS. American oil Chemists society official and tentative methods 1963 Revised.

13 Brolley DS and RH McCormack J.Am. Oil Chemists 'Soc., 195027 84-7.

14 Lundberg WO Autoxidation and antioxidants, Interscience ublishers_1963 (New York).

15 Gilmon R, Levenson HS and LW Elder, oil and soap 1946 23, 248-52

16 Wilbur KM, Bergheim F and OW Shapiro Arch. Biochem., 195824 305-13

17 Hamilton RJ and J Cast Spectral Properties of Lipids, 1999.

18 Awson H Foods oils and fats, technology, utilization and nutrition. 1999

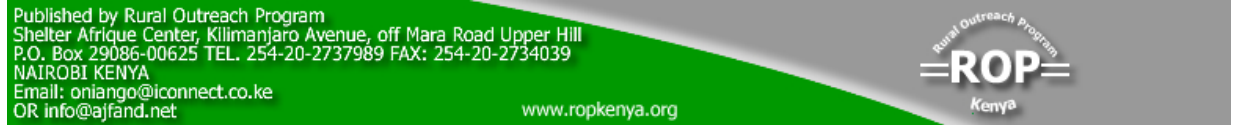

